\title{
Biostimulatory Action of Vegetal Protein Hydrolysate and the Configuration of Fruit Physicochemical Characteristics in Grafted Watermelon
}

\author{
Georgios A. Soteriou ${ }^{1}{ }^{\circ}$, Youssef Rouphael ${ }^{2}{ }^{(0}$, Maria G. Emmanouilidou ${ }^{3}{ }^{(}$, Chrystalla Antoniou $^{1}$, \\ Angelos C. Kyratzis ${ }^{1}$ and Marios C. Kyriacou ${ }^{1, *(\mathbb{D}}$ \\ 1 Postharvest Technology Laboratory, Agricultural Research Institute, Nicosia 1516, Cyprus; \\ soteriou@ari.gov.cy (G.A.S.); chrystalla.antoniou@ari.gov.cy (C.A.); a.kyratzis@ari.gov.cy (A.C.K.) \\ 2 Department of Agricultural Sciences, University of Naples Federico II, 80055 Portici, Italy; \\ youssef.rouphael@unina.it \\ 3 Olive Technology Laboratory, Agricultural Research Institute, Nicosia 1516, Cyprus; \\ maria.emmanouelidou@ari.gov.cy \\ * Correspondence: m.kyriacou@ari.gov.cy; Tel.: +357-22-403221; Fax: +357-22-316770
}

\section{check for}

updates

Citation: Soteriou, G.A.; Rouphael, Y.; Emmanouilidou, M.G.; Antoniou,

C.; Kyratzis, A.C.; Kyriacou, M.C. Biostimulatory Action of Vegetal Protein Hydrolysate and the Configuration of Fruit Physicochemical Characteristics in Grafted Watermelon. Horticulturae 2021, 7, 313. https://doi.org/10.3390 /horticulturae7090313

Academic Editor: Nazim Gruda

Received: 5 August 2021

Accepted: 14 September 2021

Published: 15 September 2021

Publisher's Note: MDPI stays neutral with regard to jurisdictional claims in published maps and institutional affiliations.

Copyright: (c) 2021 by the authors. Licensee MDPI, Basel, Switzerland. This article is an open access article distributed under the terms and conditions of the Creative Commons Attribution (CC BY) license (https:// creativecommons.org/licenses/by/ $4.0 /)$.

\begin{abstract}
Foliar application of a vegetal-derived protein hydrolysate as a biostimulant was assessed for possible interaction with the ripening of diploid watermelon grafted onto interspecific hybrid rootstock. Assessment encompassed crop performance; fruit morphometric and sensory quality traits; soluble carbohydrates; macrominerals; and bioactive composition at 10, 20, 30, 40, and 50 days post anthesis (dpa). The biostimulant effect on yield components was confounded by the vigorous rootstock effect. Pulp firmness declined precipitously with cell enlargement from 10 to $30 \mathrm{dpa}$, and the biostimulant phyto-hormonal potential on firmness and rind thickness was masked by grafting. Pulp colorimetry was determined solely by ripening and peaked at $40 \mathrm{dpa}$. The biostimulant effect reduced lycopene content by $8 \%$ compared to the control. Total sugars coevolved with soluble solids content, peaked at $30 \mathrm{dpa}$, and then stabilized. Fructose and glucose prevailed during rapid fruit growth from 10 to $30 \mathrm{dpa}$ and sucrose prevailed at advanced ripeness between 40-50 dpa, whereas acidity peaked at $20 \mathrm{dpa}$ and then decreased. Potassium, which was the most abundant micromineral, peaked before full ripeness at $30 \mathrm{dpa}$. The biostimulant effect on the watermelon fruit ripening process is not granted, at least regarding the conditions this study was carried out under. The absence of biostimulant effect might relate to rootstock vigorousness, the grafted watermelon physiology, or the type of biostimulant used.
\end{abstract}

Keywords: Citrullus lanatus (Thunb.) Matsum. and Nakai; functional quality; biostimulant; sugars; texture; sustainable horticulture; rootstock; mineral profile

\section{Introduction}

Grafting onto cucurbit rootstocks is an established practice in watermelon cultivation as an effective tool to ensure crop performance without any adverse effects on the environment or human health [1,2]. By exploiting rootstock superior traits, grafts can be deployed under diverse agro-environmental conditions that are otherwise prohibitive for growing watermelon. Extensive research on watermelon demonstrated that serious impediments stemming from soil-borne pathogens, high salinity, heat stress, alkalinity, etc., could be successfully addressed by grafting onto a suitable rootstock [3]. Another promising, innovative, and eco-friendly approach for enhancing crop productivity, yield stability, and quality of vegetables, would be the use of microbial (e.g., arbuscular mycorrhizal fungi or plant growth promoting rhizobacteria) or non-microbial plant biostimulants (e.g., humic substances, seaweed extracts, vegetal or animal-derived protein hydrolysates, or silicon) [4]. In many cases, vegetal-derived protein hydrolysates have demonstrated effective biostimulant activity through the modulation of a wide array of biochemical, 
physiological, and molecular processes that trigger phyto-hormonal properties, stimulate plant metabolism, increase water and nutrient use efficiency, promote microbial activity, and enhance the resilience against abiotic stressors (e.g., salinity, drought, and extreme temperature) [4-8].

In addition to optimizing crop performance and yield under adverse conditions, rootstock selection may exert an effective role in the configuration of the scion's fruit sensory quality traits $[9,10]$. Moreover, rootstock selection has been demonstrated to impact the phytochemical content of the scion's fruit, thereby mediating its potential bioactive value [1]. Extensive information is currently available regarding rootstockmediated effects on scion's yield performance, physico-chemical, bioactive, and sensory components of fruit quality under field conditions. For watermelon in particular, several reports showed that grafting onto Cucurbita maxima $\times$ C. moschata interspecific rootstocks may improve flesh firmness, color, and lycopene content as well as fruit postharvest performance [11]. However, the moderate reduction of fruit total sugar content or excessive increase of firmness was observed in some rootstock-scion combinations [1]. Further improvement of fruit sensory quality could also be pursued through the application of specific plant biostimulants. Such improvement has been previously documented for the fruit firmness [12,13], coloration [14,15], carotenoid content [16,17], and soluble solids content (SSC; [16-18]) of various fruits (apricot, strawberry, pepper, sweet cherry, tomato) in response to the application of biostimulants such as humic substances, seaweed extracts, and protein hydrolysates. However, analogous information on watermelon quality traits remains scarce.

The evolution of fruit organoleptic characteristics during ripening is mainly determined genetically by the watermelon cultivar, but it can also be influenced by agrienvironmental factors, including grafting onto select rootstocks. In particular, grafting watermelon onto interspecific Cucurbita maxima $\times$ C. moschata rootstocks has been shown to retard fruit ripening, manifested in the delayed climax of fruit chroma development and the build-up of pulp lycopene and soluble carbohydrate content [9,19]. Analogous studies on the effect of plant biostimulants on the fruit ripening of watermelon are currently missing, although various biostimulant types appear to affect the fruit ripening process in several other crops. Specifically, several studies showed that plant biostimulants may interfere with the ripening of climacteric (apricot) and non-climacteric (grapevines, sweet cherry) fruits mainly by promoting the accumulation of fruit sugars and by improving fruit chromatometric parameters $[15,20,21]$.

In accordance with the above, the current work was implemented in order to assess how the foliar application of a vegetal-derived protein hydrolysate biostimulant $\left(\right.$ Trainer $^{\circledR}$ ) may interact with the fruit ripening process of diploid watermelon grafted onto interspecific hybrid rootstock (C. maxima (Duchesne) $\times$ C. moschata (Duchesne ex Poir)). The biostimulant effect was assessed on crop performance and the evolution of fruit morphometric characteristics. Moreover, fruit sensory quality traits (pulp colorimetry, firmness, sweetness index), carbohydrate composition (fructose, glucose, sucrose), mineral (potassium, calcium, phosphorus, magnesium), and bioactive content (lycopene) were monitored at progressive maturity stages. As the use of biostimulants on horticultural crops gains ground and the application of grafting on crops such as watermelon has become ubiquitous, the current study constitutes a novel contribution to our understanding of the potentially interactive effects of vegetal-derived biostimulants with the configuration of fruit physicochemical characteristics along the ripening continuum.

\section{Materials and Methods}

\subsection{Plant Material and Growing Conditions}

Watermelon transplants were planted in alkaline ( $\mathrm{pH}$ 7.5) clay-loam soil at the Tochni Experimental Station $\left(34^{\circ} 44^{\prime} 00^{\prime \prime} \mathrm{N} ; 33^{\circ} 20^{\prime} 15^{\prime \prime} \mathrm{E}\right)$ of the Agricultural Research Institute of Cyprus. The study was carried out between May and July in an area characterized by typical Mediterranean climate with an average precipitation of $370 \mathrm{~mm}$, occurring mainly 
between November and March, and a mean day-time temperature ranging from 28 to $38^{\circ} \mathrm{C}$ during summer months. Large-fruited (8-10 kg), diploid watermelon, cv. Obla, was grafted onto inter-specific C. maxima $\times$ C. moschata hybrid rootstock 'N-101'. Grafts were made by a commercial nursery, as described previously by Soteriou and Kyriacou [22]. Seeds from rootstock and scion hybrids were sowed in different plug trays. The substrate consisted of vermiculite. Seeds remained at 95-98\% relative humidity and $25{ }^{\circ} \mathrm{C}$ temperature until germination. Upon germination, the trays were placed for 14-15 days in the greenhouse until grafting. Grafts were made using the approach grafting method. Grafting was facilitated after the appearance of the first true leaf on seedlings by performing a downward slanted incision below the cotyledons on the rootstock and an upward identical incision on the scion. The two incisions were assembled and held together by a plastic clip. Upon grafting, seedlings were placed in a healing chamber under specific conditions for 6-7 days. Temperature was $25^{\circ} \mathrm{C}$ and relative humidity was gradually decreased from $95-98 \%$ to $85-89 \%$. After the grafts were removed from the healing chamber, they were placed in the greenhouse for 15 days before transplanting. Temperature was $25^{\circ} \mathrm{C} / 18{ }^{\circ} \mathrm{C}$ and relative humidity $65-75 \%$. Base dressing with $350 \mathrm{~kg} \cdot \mathrm{ha}^{-1}$ of compound fertilizer $14 \mathrm{~N}-9.6 \mathrm{P}-7.5 \mathrm{~K}$ was incorporated into the soil prior to planting. Plant spacing was set at $1.0 \mathrm{~m}$ on the

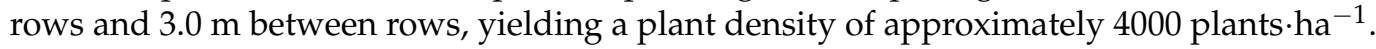
A drip irrigation system was used, and fertigation was applied starting from ten days after transplanting [22]. Recommended standard guidelines for pest and disease control practices were applied. Female flower anthesis and fruit setting was initiated approximately 40 days post-transplanting. Fruit age monitoring was implemented with daily inspection of all flowers and tagging at anthesis (fruit setting). Four replicate plots arranged in a completely randomized design were used for each stage of maturity: 10, 20, 30, 40, and 50 days post-anthesis (dpa).

\subsection{Biostimulant Characteristics and Application}

Biostimulant treatment was performed by spraying the plant-derived protein hydrolysate biostimulant Trainer ${ }^{\circledR}$, provided by Hello Nature Italia SRL, Rivoli Veronese, Verona, Italy. Commercial protein hydrolysate-based biostimulants such as Trainer ${ }^{\circledR}$ contain mainly peptides and amino acids and, to a lower extent, phenolic compounds (8.93 mg of gallic acid equivalent $\mathrm{g}^{-1}$ and $0.95 \mathrm{mg}$ of quercetin equivalent per $\mathrm{g}^{-1}$ of total phenolics and flavonoids on fresh weight basis; [23]). In addition, its composition comprises specific amino acids (Ala, Arg, Asp, Cys, Glu, Gly, His, Ile, Leu, Lys, Met, Phe, Pro, Ser, Thr, Trp, Tyr, and Val) and no phytohormones. Trainer ${ }^{\circledR}$ was applied as a foliar aqueous solution $\left(3 \mathrm{~mL} \mathrm{~L}^{-1}\right)$. The watermelon plants of each plot were sprayed until the run-off point under favorable weather forecast (no rainfalls expected in the following $24 \mathrm{~h}$ ). Application dose increased from approximately 0.31 to $1.25 \mathrm{~L}$ per plant depending on crop growth stage and hence plant total leaf area. Biostimulant application commenced ten days after planting and was repeated every ten days. The application of biostimulant was performed five times in total during the growing season (Table S1). Control plots were sprayed with water only.

\subsection{Fruit Age Monitoring, Sampling Procedures, Yield, and Morphometric Traits}

Yield and the number of fruits per hectare were estimated based on the data of the 40 dpa plots. Undersized fruit were considered unmarketable. Six marketable fruits from each dpa plot were randomly chosen to assess quality. All fruit sampled for quality assessment had been set on the same calendar date \pm 1 day and harvested simultaneously on the date corresponding to each plot's assigned dpa stage. Fruit weight and equatorial and meridian diameters were determined with a Vernier caliper at harvest. Fruit rind was measured at two representative points on each cross-sectioned fruit using an electronic caliper. 


\subsection{Fruit Pulp Texture and Colorimetry}

Pulp firmness was determined using a TA.XT plus Texture Analyser (Stable Micro Systems, Surrey, UK) carrying a $50 \mathrm{~kg}$ load cell and a compound puncture probe, consisting of eight $4 \mathrm{~mm}$-diameter probes in a circular $42 \mathrm{~mm}$-diameter arrangement, operated at $2 \mathrm{~mm} \cdot \mathrm{s}^{-1}$ test speed. Pulp firmness was determined as the maximum force of resistance to penetration (kg-force) around the heart of each cross-sectioned fruit to a displacement depth of $50 \mathrm{~mm}$.

Flesh color was analyzed at two loci in the heart region of each cross-sectioned fruit using an $8 \mathrm{~mm}$-aperture Minolta CR-400 Chroma Meter (Minolta, Osaka, Japan). Measurements were performed in the CIELAB color space for colorimetric parameters $\mathrm{L}$ *, $a^{*}$, chroma $\left(C^{*}\right)$, and hue angle $\left(h^{\circ} ;[24]\right)$.

\subsection{Soluble Carbohydrates, Lycopene, and Titratable Acidity}

The heart of each fruit was excised and homogenized under low speed to prevent foaming. The homogenate was filtered through double cheesecloth, and the soluble solids content (SSC) of the filtered juice at $20{ }^{\circ} \mathrm{C}$ was determined on a digital, temperaturecompensating refractometer (RFM870; Bellingham-Stanley Ltd., Kent, UK). The pH of the juice was measured with a $\mathrm{pH}$-electrode (SevenMulti; Mettler-Toledo $\mathrm{GmbH}$, Schwerzenbach, Switzerland). A $20 \mathrm{~mL}$ aliquot of the juice was titrated with $0.1 \mathrm{M} \mathrm{NaOH}$ to a $\mathrm{pH}$ endpoint of 8.2 on an automatic titrator (794 Basic Trinitro; Metrohm Ltd., Herisau, Switzerland) to determine its titratable acidity, which was expressed as $\% w / v$ content of malic acid.

Part of the homogenate was transferred to $50 \mathrm{~mL}$ falcon tubes, instantly frozen in liquid nitrogen, and then stored at $-80^{\circ} \mathrm{C}$ for phytochemical analyses. Pulp lycopene content was extracted in hexane and determined according to the method of Fish and Davis [25] based on the absorbance at $503 \mathrm{~nm}$ measured on a Jasco V-550 UV-VIS spectrophotometer (Jasco Corp., Tokyo, Japan) and using the extinction coefficient of $17.2 \times 104 \mathrm{M}^{-1} \mathrm{~cm}^{-1}$. Non-structural carbohydrates (glucose, fructose, and sucrose) in the juice were separated, identified, and quantitated by liquid chromatography on an Agilent HPLC-RID 1260 Series system (Agilent Technologies, Santa Clara, CA, USA). Separation was performed on a $4.6 \times 250 \mathrm{~mm}$ carbohydrate column at $35^{\circ} \mathrm{C}$ (Waters, Milford, MA, USA). Separation conditions were as detailed in Kyriacou et al. [26] using an acetonitrile:water (75:25) mobile phase at a flow rate of $1.4 \mathrm{~mL} \cdot \mathrm{min}^{-1}$. External standard calibrating curves constructed for quantification had a coefficient of determination of $\left(R^{2}\right)>0.9999$. Recovery trials were on the order of $100 \%$ in all cases. Results were expressed in $\mathrm{mg} \mathrm{mL}^{-1}$.

\subsection{Mineral Analysis}

The concentrations of macro-minerals, nitrate, and sodium were determined on a Dionex ICS-3000 ion chromatograph (Dionex, Sunnyvale, CA, USA) coupled to a conductivity detector, as previously described in detail by Rouphael et al. [17]. The results were expressed in $\mathrm{g} \mathrm{kg}^{-1}$ on a dry weight $(\mathrm{dw})$ basis.

\subsection{Experimental Design and Statistical Analysis}

A factorial completely randomized design was applied with two biostimulant treatments (non-treated control or protein hydrolysate $(\mathrm{PH})$ ) and five fruit maturity stages (10, 20, 30, 40, or $50 \mathrm{dpa}$ ). Each field plot (experimental unit) consisted of five plants and was replicated four times. At each stage of maturity, six fruits were sampled from each plot. Replicate means were derived from the individual values of six fruits. Data were subjected to analysis of variance (ANOVA) and means comparison according to the Tukey-Kramer multiple range test using SAS 9.1. statistical package (SAS Institute, Cary, NC, USA). Preliminary experiments yielded very similar results to those reported in the current work. 


\section{Results and Discussion}

\subsection{Yield Components and Fruit Morphological Characteristics}

The marketable yield of biostimulant-treated and control watermelon crop averaged $79.9 \pm 4.4$ tons $\left(\mathrm{ha}^{-1}\right)$ with a mean fruit weight of $7.8 \pm 0.2 \mathrm{~kg}$ (Table 1). Biostimulant application did not have a significant effect on marketable yield, number of fruits per hectare, or fruit size, expressed as unit fruit weight and fruit diameter (Table 1). Watermelon fruit size and fruit number are primarily determined genetically and demonstrate wide variation among watermelon cultivars [27]. However, these variables can be affected to some extent by several agro-environmental factors such as plant spacing and grafting [22,28]. In the present study, the use of seedlings grafted on vigorous rootstock could be one of the reasons why the biostimulant application was not effective in improving crop yield components such as the number of fruits (no. ha ${ }^{-1}$ ) and fruit weight $(\mathrm{kg})$. Biostimulant efficiency could have potentially yielded positive results had a less robust rootstock been used. Biostimulant application is usually effective when applied on crops subjected to abiotic stresses and sub-optimal conditions [2]. In our study, cv. Obla possibly reached its maximum yield potential as a consequence of being grafted onto vigorous $C$. maxima $\times C$. moschata rootstock and grown under optimum nutrient and water management conditions. Indicatively, it is reported that, under these optimum conditions, the control treatments of cv. Obla yielded $79.1 \mathrm{tha}^{-1}$, which is $52 \%$ above the regional average ( $52 \mathrm{t} \mathrm{ha}^{-1}$; [22]).

Table 1. Mean comparisons for tradable yield, fruit number, fruit mean weight, and fruit diameter of the watermelon cv. Obla with protein hydrolysate application $(\mathrm{PH})$ or without (Control).

\begin{tabular}{ccccc}
\hline Biostimulant & $\begin{array}{c}\text { Yield } \\
\left(\mathbf{t ~ h a}^{-\mathbf{1}} \mathbf{)}\right.\end{array}$ & $\begin{array}{c}\text { Fruit Number } \\
\text { (Fruits ha }^{-\mathbf{1}} \mathbf{)}\end{array}$ & $\begin{array}{c}\text { Fruit Weight } \\
\mathbf{( k g )}\end{array}$ & $\begin{array}{c}\text { Fruit Diameter } \\
\mathbf{( \mathbf { c m } )}\end{array}$ \\
\hline Control & $79.1 \pm 4.6$ & $10,181 \pm 412$ & $7.77 \pm 0.3$ & $22.76 \pm 0.32$ \\
PH & $80.6 \pm 8.2$ & $10,181 \pm 548$ & $7.80 \pm 0.4$ & $22.96 \pm 0.20$ \\
& $\mathrm{~ns}$ & $\mathrm{~ns}$ & $\mathrm{~ns}$ & $\mathrm{~ns}$ \\
\hline
\end{tabular}

ns = non-significant effect.

Fruit sampling for quality analysis was performed during the final phase of watermelon fruit development (Figure 1), when cell division had ceased and further fruit growth was accomplished only through cell expansion, culminating when the fruit has assumed full size $[29,30]$. This period is characterized by an increase in parenchyma cell size and, consequently, a decrease in cell density per fruit pulp unit area or volume [29,30]. Fruit size in the current study, as determined by fruit weight $(\mathrm{kg})$ and longitudinal diameter $(\mathrm{cm})$ increased by $257 \%$ and $60 \%$, respectively, between 10 and 30 dpa and subsequently only by $16 \%$ and $5 \%$ during the $30-40$ dpa period (Figure 1). No significant differences were observed between control and biostimulant-treated plants when considering fruit weight and diameter.

\subsection{Fruit Pulp Texture and Rind Thickness}

Pulp firmness remained stable between 10 and 20 dpa and declined significantly from 20 to $30 \mathrm{dpa}$, after which it remained unaltered up to $50 \mathrm{dpa}$ (Tables 2 and S2). The nominal decline in pulp firmness was most pronounced during the period of 10-30 dpa, during which the incremental decrease was $26 \%$, compared to a mere $8 \%$ decrease in the 30-50 dpa period. The observed decrease in pulp firmness during the 10-30 dpa period could be related to the onset of cell enlargement and the decrease in cell density of the fruit pulp, concomitant with the rapid fruit growth observed in the same period [31]. Nevertheless, pulp firmness did not change significantly even up to $50 \mathrm{dpa}$, compared to $30 \mathrm{dpa}$, and remained within the threshold for consumer acceptability [22,32]. Maintaining an acceptable pulp firmness up to $50 \mathrm{dpa}$ could be considered advantageous, both in terms of allowing for a longer pre-harvest time window of marketability, during which the fruit may be retained on the plant before being placed on the market, but also because high pulp firmness at harvest might extend the shelf-life of the fruit [9]. In this study, although 
protein hydrolysate biostimulant application was initiated early during crop establishment and was applied at 10-day intervals throughout the season, it did not have a significant effect on pulp firmness (Tables 2 and S2). The effect of biostimulants on firmness seems to be influenced by the type of product used as well as the type of the crop onto which they are applied. For instance, similarly to our study, no effect on fruit firmness was recorded on melon (Cucumis melo) by Fernando et al. [33] or on apple (Malus $\times$ domestica) by Soppelsa et al. [34]. In both aforementioned studies a protein hydrolysate biostimulant was applied along with several other types of biostimulants (humic acids, macroseaweed extracts, microalga hydrolysate, mix of amino acids, chitosan, etc.) on an experimental organic orchard. By contrast, when biostimulants based on humic acids were applied on apricot (Prunus armeniaca) [12] and biostimulants based on chitosan were applied on strawberry (Fragaria $\times$ ananassa) [13], both were effective in improving fruit firmness. It is very possible that, in our current study, the phyto-hormonal potential of protein hydrolysate biostimulant was masked by the pronounced rootstock effect on pulp firmness. A plethora of studies have identified pulp firmness as the quality trait most frequently and consistently improved by grafting commercial watermelon cultivars onto inter-specific hybrid rootstocks [22,35]. This effect is associated with increased fruit cell density and altered cell wall characteristics, and it is possibly related to the grafting-mediated differentiation of scion gene expression, which encompasses the over-regulation of cytokine and other metabolites of primary and secondary metabolism [36-39].



Figure 1. Regression of fruit weight (A) and diameter (B), with maturity for watermelon fruit harvested at 10, 20, 30, 40, and 50 days post-anthesis from plants with (PH) or without (Control) protein hydrolysate biostimulant application. Data points represent the means of four replicates consisting of six sample fruits each. 


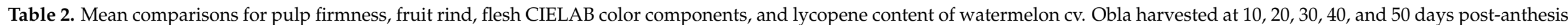
with $(\mathrm{PH})$ or without (Control) protein hydrolysate biostimulant application.

\begin{tabular}{|c|c|c|c|c|c|c|c|c|c|c|c|c|c|c|}
\hline \multirow[t]{2}{*}{$\begin{array}{l}\text { Source of } \\
\text { Variance }\end{array}$} & \multicolumn{2}{|l|}{ Firmness } & \multicolumn{2}{|l|}{ Rind } & \multicolumn{2}{|l|}{$\mathbf{L}^{*}$} & \multicolumn{2}{|l|}{$C^{*}$} & \multicolumn{2}{|l|}{$\mathbf{h}^{\circ}$} & \multicolumn{2}{|l|}{$a^{*}$} & \multicolumn{2}{|l|}{ Lycopene } \\
\hline & (kg-force) & & $(\mathrm{mm})$ & & $(0-100)$ & & $\sqrt{ }\left(a^{* 2}+b^{* 2}\right)$ & & $\left(0-360^{\circ}\right)$ & & $(0-60)$ & & $\left(\mu \mathrm{g} \mathrm{g}^{-1}\right.$ f.w. & \\
\hline \multicolumn{15}{|c|}{ Biostimulant } \\
\hline Control & $4.15 \pm 0.17$ & & $9.42 \pm 0.53$ & & $52.76 \pm 2.71$ & & $26.11 \pm 2.23$ & & $47.57 \pm 5.96$ & & $19.96 \pm 2.60$ & & $49.42 \pm 7.31$ & $\mathrm{a}$ \\
\hline \multirow[t]{2}{*}{$\mathrm{PH}$} & $3.96 \pm 0.15$ & & $9.41 \pm 0.67$ & & $53.76 \pm 2.98$ & & $25.53 \pm 2.27$ & & $48.16 \pm 6.17$ & & $19.51 \pm 2.61$ & & $44.67 \pm 6.71$ & $\mathrm{~b}$ \\
\hline & ns & & ns & & ns & & ns & & ns & & ns & & $*$ & \\
\hline \multicolumn{15}{|c|}{ Days post-anthesis } \\
\hline 10 & $4.91 \pm 0.12$ & $\mathrm{a}$ & $4.55 \pm 0.31$ & $\mathrm{~b}$ & $77.42 \pm 0.56$ & a & $8.63 \pm 0.28$ & $\mathrm{~d}$ & $103.06 \pm 0.25$ & a & $-1.94 \pm 0.07$ & $\mathrm{~d}$ & $0.27 \pm 0.07$ & e \\
\hline 30 & $3.65 \pm 0.13$ & $\mathrm{~b}$ & $11.34 \pm 0.35$ & $\mathrm{a}$ & $45.95 \pm 0.64$ & c & $31.36 \pm 0.58$ & $\mathrm{~b}$ & $32.03 \pm 0.27$ & $\mathrm{c}$ & $26.56 \pm 0.43$ & $\mathrm{~b}$ & $55.96 \pm 1.47$ & $c$ \\
\hline 40 & $3.42 \pm 0.11$ & $\mathrm{~b}$ & $10.68 \pm 0.37$ & $\mathrm{a}$ & $42.41 \pm 0.64$ & $\mathrm{~d}$ & $36.35 \pm 0.58$ & $\mathrm{a}$ & $31.94 \pm 0.47$ & $c$ & $30.79 \pm 0.44$ & $\mathrm{a}$ & $87.95 \pm 2.55$ & a \\
\hline 50 & $3.38 \pm 0.23$ & $\mathrm{~b}$ & $\underset{* * *}{10.74 \pm 0.66}$ & $\mathrm{a}$ & $\underset{* * *}{42.57 \pm 0.93}$ & $\mathrm{~d}$ & $\underset{* * *}{34.97 \pm 0.66}$ & $\mathrm{a}$ & $\underset{* * *}{33.0 \pm 0} 0.25$ & $\mathrm{bc}$ & $\underset{* * *}{29.27 \pm 0.52}$ & $\mathrm{a}$ & $\underset{* * *}{76.79} \pm 2.97$ & $\mathrm{~b}$ \\
\hline
\end{tabular}

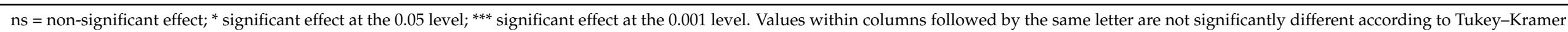
HSD. 
While flesh firmness may play a crucial role in watermelon quality and may also contribute to longer shelf life, the rind thickness of the watermelon fruit by rule affects the post-harvest management and postharvest performance of the fruit [9]. In the present study, fruit rind thickness increased by $123 \%$ until $20 \mathrm{dpa}$ and then remained unchanged (Tables 2 and S2). Fruit rind thickness was determined solely by fruit age because biostimulant application did not exert a significant effect. Similar results were reported by Fernando et al. [33] when Trichoderma-based biostimulants were applied on melon (Cucumis melo L.). It would appear that rind thickness is largely determined genetically for each cultivar, although a significant effect on rind thickness has been documented in some studies in response to grafting $[11,40]$.

\subsection{Colorimetry}

The evolution of pulp colorimetric variables was determined solely by the fruit ripening stage (Tables 2 and S2). At $10 \mathrm{dpa}$, the immature fruit pulp was described by a very light greenish-yellowish off-white color with no sign of red, as indicated by the high values for lightness $\left(\mathrm{L}^{*}\right)$ and hue angle $\left(\mathrm{h}^{\circ}\right)$ on one hand, and, on the other, the low value for chroma $\left(C^{*}\right)$ that lies close to the achromatic center of the CIELAB colorimetric sphere [24]. Lightness progressively decreased (darker pulp) and the pulp chroma intensified, as denoted by increasing chroma values $\left(C^{*}\right)$, to attain its most intense color at $40 \mathrm{dpa}$ when the fruit was fully ripe. Thereafter, no differentiation was observed concerning pulp lightness and chroma values. Colorimetric parameter $\mathrm{a}^{*}$, which denotes unidirectionally the intensity of pulp redness, demonstrated similar development during ripening to that of $L^{*}$ and $h^{\circ}$. A decrease in hue angle, $\mathrm{h}^{\circ}$, indicated that a more reddish pulp color was obtained at $30 \mathrm{dpa}$ onwards. Furthermore, the evolution of watermelon flesh coloration in our current study was not significantly affected or interacted by the foliar application of protein hydrolysate biostimulant (Tables 2 and S2). Several studies showed that the efficacy of biostimulants in modulating fruit coloration depends upon both crop species and biostimulant formulation as well as the prevailing open field or greenhouse environmental conditions. For example, similarly to our results, the use of an amino acids based biostimulant did not improve apricot (Prunus armeniaca) color [21]. In contrast, biostimulants composed of vitamins and amino acids or brown seaweed extracts $(A$. nodosum) improved coloration in pepper (Capsicum spp.) and sweet cherry (Prunus avium L.), respectively [14,15].

\subsection{Lycopene Content}

Watermelon pulp lycopene content may provide an additional insight into the development of pulp color in the course of ripening and the potential effect of vegetal-based protein hydrolysate application because lycopene is the key carotenoid compound responsible for the red coloration of watermelon flesh [41]. As expected, pulp lycopene content correlated significantly with color components a $*(r=0.93, p<0.001)$ and $C^{*}(r=0.96$, $p<0.001)$ and negatively with $\mathrm{L}^{*}(\mathrm{r}=-0.90, p<0.001)$ and $\mathrm{h}^{\circ}(\mathrm{r}=-0.75, p<0.001)$, meaning that fruits with darker (lower $L^{*}$ values), more intense (higher $C^{*}$ values) red flesh (higher values of $\mathrm{a}^{*}$ and lower values of $\mathrm{h}^{\circ}$ ) were richer in lycopene content. In this study, the lycopene content of red-fleshed cv. Obla grafted onto a C. maxima $\times$ C. moschata interspecific rootstock started to develop, along with the flesh color, in the fruit locular regions after $10 \mathrm{dpa}$ (Tables 2 and S2). It extended thereafter progressively to the placental region of the fruit where, along with red color intensity (CIELAB component $\mathrm{a}^{*}$ ), it peaked at around $40 \mathrm{dpa}$. Lycopene content declined thereafter, while all CIELAB chromatometric parameters remained unchanged. The latter verifies reports of other studies that flesh color cannot be used to estimate lycopene content accurately based only on surface colorimetry [31,42]. On the other hand, the foliar application of protein hydrolysate biostimulant $\left(\right.$ Trainer $\left.^{\circledR}\right)$ did not appear effective in enhancing watermelon lycopene content in this study (Tables 2 and S2). On the contrary, its application reduced flesh lycopene content by about $8 \%$ compared to the control. This was not expected as other reports on the application of Trainer ${ }^{\circledR}$ on tomato crop (Solanum lycopersicum L.) showed an increase in fruit lycopene 
content ranging from $34.9 \%$ to $125 \%$ compared to the control $[16,17]$. With respect to the tomato crop, the increased level of lycopene content was associated with improved potassium $\left(\mathrm{K}^{+}\right)$assimilation and antioxidants biosynthesis in plant tissues after the application of protein hydrolysates $[16,17]$. A possible explanation for our contrasting results could be attributed to the different mechanisms controlling the biosynthesis and accumulation of carotenoids in tomato and watermelon fruit and the possible phyto-hormonal effect that Trainer ${ }^{\circledR}$ could have on tomato ethylene biosynthesis. In particular, it is reported that the ripening processes in the climacteric tomato fruit, including lycopene synthesis and accumulation, are ethylene-dependent and could be affected by biostimulant hormonal action, while the latter does not apply to the non-climacteric watermelon [43]. The decrease in lycopene content, as observed in our study, after biostimulant application warrants further investigation.

\subsection{Soluble Carbohydrates}

Juice soluble solid content (SSC) is the most critical quality trait of watermelon and depends mainly on the accumulation of mono- and di-saccharides and partly on other solutes (proteins, organic acids, etc.) found in watermelon juice [44]. In this study, total sugar content was significantly correlated with SSC $(r=0.99, p<0.001)$ as the evolution of juice SSC during fruit ripening was mainly driven by the total sugar content of the juice (Tables 3 and S3). The observed increase in total sugar content up to 30 dpa coevolved with the increase in SSC, while both remained unchanged thereafter. Our results indicate that the SSC of grafted cv. Obla peaked at $30 \mathrm{dpa}$, which is 5-10 days earlier than previous reports [31]. In fact, the SSC levels (12-12.5 ${ }^{\circ}$ Brix) of fruits beyond this age (30-50 dpa) exceeded what is customarily considered an optimum organoleptic profile $\left(10-11^{\circ} \mathrm{Brix}\right)$ for watermelon (Tables 3 and S3) [9,27]. However, the flesh color of cv. Obla was lighter (higher $L^{*}$ values) and less intense (lower a ${ }^{*}$ and $C^{*}$ values) at $30 \mathrm{dpa}$ compared to 40 and 50 dpa. Attaining maximum SSC at $30 \mathrm{dpa}$ is nevertheless an important commercial feature of cv. Obla, which may be ranked as an early variety, regardless of its lighter flesh color. Significant differentiation was observed for fructose, glucose, and sucrose content in response to fruit maturity. Fructose content was higher than glucose throughout the ripening progress, corroborating similar previous studies [32]. Fructose and glucose content increased with fruit age up to $20 \mathrm{dpa}$ but began to decrease at 40 and $30 \mathrm{dpa}$ onwards, respectively. An inverse trend was observed with sucrose content, which increased up to $50 \mathrm{dpa}$. The concentration of fructose and glucose as a fraction of total sugars declined with ripening as sucrose concentration increased from $0 \%$ at 10 dpa to $58.5 \%$ at 50 dpa. In agreement with previous studies [32], fructose and glucose were the main substrates fueling the high metabolic demands during the period of rapid fruit growth (10-30 dpa), while sucrose levels remained low. In contrast, sucrose was the main form of depository carbohydrate accumulating during the end of fruit ripening (40-50 dpa), at the expense of monosaccharides. The latter is characteristic of grafted diploid cultivars such as cv. Obla, which tend to accumulate sucrose rather than fructose, in contrast to triploid cultivars, during fruit ripening [31]. In the current study, fruit ripening was the only factor influencing soluble sugar and SSC content evolution because the effect of biostimulant application was non-significant. It seems that protein hydrolysate-based biostimulants, such as the one used in this study (Trainer ${ }^{\circledR}$ ), are effective in increasing the soluble solids content, mostly of Solanaceae sp. crops. In contrast to our results, application of Trainer ${ }^{\circledR}$ on tomato or hot pepper increased fruit SSC [16-18]. The absence of Trainer ${ }^{\circledR}$ positive effect on grafted watermelon SSC is probably due to the same reasons analyzed above for total yield and lycopene content. Moreover, other studies on fungi-based biostimulants applied on melon (Cucumis melo) or seaweed extracts applied on strawberry fruits (Fragaria $\times$ ananassa Dush) and grapevine (Vitis vinifera L.) reported no effect of biostimulants on SSC, similarly to our findings $[20,33,45]$. 


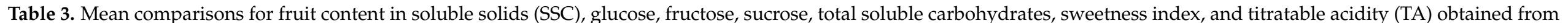
watermelon cv. Obla harvested at 10, 20,30, 40, and 50 days post-anthesis with (PH) or without (Control) protein hydrolysate biostimulant application.

\begin{tabular}{|c|c|c|c|c|c|c|c|c|c|c|c|c|c|c|}
\hline $\begin{array}{l}\text { Source of } \\
\text { Variance }\end{array}$ & $\begin{array}{l}\text { SSC } \\
(\%)\end{array}$ & & $\begin{array}{c}\text { Fructose } \\
\left(\mu \mathrm{g} \mathrm{mL} \mathrm{L}^{-1}\right)\end{array}$ & & $\begin{array}{l}\text { Glucose } \\
\left(\mu \mathrm{g} \mathrm{mL}^{-1}\right)\end{array}$ & & $\begin{array}{c}\text { Sucrose } \\
\left(\mu \mathrm{g} \mathrm{mL} L^{-1}\right)\end{array}$ & & $\begin{array}{l}\text { Total Sugars } \\
\left(\mu \mathrm{g} \mathrm{mL} \mathrm{mL}^{-1}\right)\end{array}$ & & $\begin{array}{l}\text { Sweetness } \\
\text { Index }\end{array}$ & & $\begin{array}{l}\text { TA } \\
(\%)\end{array}$ & \\
\hline \multicolumn{15}{|c|}{ Biostimulant } \\
\hline Control & $10.48 \pm 0.63$ & & $30.47 \pm 1.74$ & & $24.75 \pm 1.45$ & & $28.54 \pm 4.95$ & & $83.76 \pm 5.50$ & & $932 \pm 58$ & & $0.17 \pm 0.01$ & \\
\hline \multicolumn{15}{|c|}{ Days post-anthesis } \\
\hline 10 & $4.95 \pm 0.17$ & c & $18.16 \pm 0.91$ & $\mathrm{~d}$ & $16.28 \pm 0.88$ & $\mathrm{~d}$ & $0.01 \pm 0.01$ & $\mathrm{~d}$ & $34.45 \pm 1.78$ & c & $395 \pm 20$ & $\mathrm{~d}$ & $0.16 \pm 0.01$ & $\mathrm{~b}$ \\
\hline 20 & $9.99 \pm 0.20$ & $\mathrm{~b}$ & $40.42 \pm 0.57$ & a & $35.08 \pm 0.66$ & $\mathrm{a}$ & $4.66 \pm 0.67$ & $\mathrm{~d}$ & $80.16 \pm 1.59$ & $\mathrm{~b}$ & $920 \pm 17$ & $\mathrm{c}$ & $0.20 \pm 0.01$ & $\mathrm{a}$ \\
\hline 40 & $12.93 \pm 0.18$ & $\mathrm{a}$ & $29.76 \pm 0.51$ & $\mathrm{~b}$ & $23.51 \pm 0.64$ & $\mathrm{c}$ & $51.57 \pm 1.68$ & $\mathrm{~b}$ & $104.84 \pm 1.08$ & $\mathrm{a}$ & $1143 \pm 10$ & $\mathrm{a}$ & $0.13 \pm 0.01$ & $\mathrm{c}$ \\
\hline 50 & $\underset{* * *}{12.43 \pm 0.14}$ & $\mathrm{a}$ & $\underset{* * *}{23.62 \pm 0.61}$ & c & $\underset{* * *}{17.55 \pm 0.63}$ & $\mathrm{~d}$ & $\underset{* * *}{57.58 \pm 1.63}$ & $\mathrm{a}$ & $\underset{* * *}{98.76} \pm 0.97$ & a & $\begin{array}{c}1066 \pm 9 \\
* * *\end{array}$ & $\mathrm{~b}$ & $\underset{* * *}{0.15 \pm 0.01}$ & $\mathrm{bc}$ \\
\hline
\end{tabular}

ns = non-significant effect; ${ }^{* * *}$ significant effect at the 0.001 level. Values within columns followed by the same letter are not significantly different according to Tukey-Kramer HSD Test ( $\left.p<0.05\right)$. 


\subsection{Sweetness Index and Titratable Acidity}

Sweetness Index (SI) is an objective method for assessing sweetness in fresh horticultural products. It is calculated on the basis of the relative contributions of glucose, fructose, and sucrose to the total concentration of soluble carbohydrates, and it takes into account the differential intensity of sweetness sensation attributed to each of these sugars [46]. Our results underscore the importance of sweetness assessment by calculating SI in addition to the determination of total sugars and soluble solids content. As already mentioned, the total sugar content essentially determined the soluble solids content from 10 to $50 \mathrm{dpa}$. However, this was paralleled only to some extent in terms of SI, which declined from 40 to $50 \mathrm{dpa}$ (Tables 3 and S3). This decline in SI is derived from a proportionally higher decline in fructose $(-20.6 \%)$ and glucose $(-25.4 \%)$, rather than the corresponding increase in sucrose $(11.7 \%)$. It is therefore apparent that the assessment of sweetness solely on the basis of total sugars or soluble solids concentration without taking into account the individual relative sweetness factor of each contributing sugar is likely to lead to partial conclusions concerning sensory quality.

Juice acidity is another factor that must be taken into account during an objective evaluation of watermelon quality. Although watermelon fruit is generally characterized by low acidity, the perception of overall sweetness but also the sensation of freshness is affected by titratable acidity and SI balance. A balanced titratable acidity and SI ratio gives the impression of a sweet fresh fruit [31]. For example, in our study, the perception of sweetness of $20 \mathrm{dpa}$ watermelons was quite degraded compared to $30 \mathrm{dpa}$ fruits due to their increased acidity and reduced SI (Tables 3 and S3). In this study, the titratable acidity of watermelon pulp increased during the first 20 days of fruit growth. This was followed by a gradual decrease in titratable acidity, which stabilized at 40 days onwards, similar to the study of Soteriou et al. [32]. Our results showed that fruit acidity development of the grafted watermelon was determined solely by the progress of ripening. Several reports showed that, with the exception of apricot, where humic acids application reduced fruit acidity [12], the application of biostimulants usually does not affect the acidity of fruits such as tomatoes, apples, and melons [16,17,33,34].

\subsection{Mineral Content}

Potassium $(\mathrm{K})$, magnesium $(\mathrm{Mg})$, calcium $(\mathrm{Ca})$, and phosphorus $(\mathrm{P})$ were the main mineral ions found in the fruit pulp and ranged within similar levels, as described in previous studies [47]. Potassium (K) was the predominant mineral detected in the pulp dry matter because its concentration was approximately 3- to 19-fold higher than the rest of the macronutrients recorded in the fruit (Tables 4 and S4). Potassium content demonstrated significant negative correlation with SSC $(\mathrm{r}=-0.67, p<0.001)$ and total sugar $(\mathrm{r}=-0.67, p<0.001)$ content. It is noteworthy that potassium reached its minimum level towards the end of rapid fruit growth ( $30 \mathrm{dpa})$, when the fruit total sugars had maximized (Figure 1). Calcium followed a similar trend to potassium content during fruit ripening, while magnesium and phosphorus content increased at $20 \mathrm{dpa}$ and then remained unaltered throughout fruit development. Changes in the fruit magnesium and phosphorus levels were detected only up to $20 \mathrm{dpa}$, which means that any deficiency of these elements until this stage of fruit development could affect fruit quality thereafter. Biostimulant application increased only potassium content by about $8 \%$ in relation to the control. Fruit potassium content improvement after the application of legume-derived protein hydrolysate was also documented in other studies and was attributed to root growth stimulation and also to the improvement of plant capacity to absorb, translocate, and allocate nutrients by modulating cell membrane properties in different plant organs $[16,17,48]$. Increased potassium uptake in watermelon scions was also related to improved root properties (root pressure) acquired through grafting onto robust cucurbit [49-51]. Finally, the pulp dry matter content maximized at $30 \mathrm{dpa}$ and was not altered during the rest of the fruit ripening period. 



without (Control) protein hydrolysate biostimulant application.

\begin{tabular}{|c|c|c|c|c|c|c|c|c|c|c|}
\hline $\begin{array}{l}\text { Source of } \\
\text { Variance }\end{array}$ & $\begin{array}{c}K \\
\text { (g/kg d.m.) }\end{array}$ & & $\begin{array}{c}\mathrm{Mg} \\
\text { (g/kg d.m.) }\end{array}$ & & $\begin{array}{c}\text { Ca } \\
\text { (g/kg d.m.) }\end{array}$ & & $\begin{array}{c}P \\
\text { (g/kg d.m.) }\end{array}$ & & $\begin{array}{l}\text { DM } \\
(\%)\end{array}$ & \\
\hline \multicolumn{11}{|c|}{ Biostimulant } \\
\hline Control & $14.19 \pm 0.40$ & $\mathrm{~b}$ & $1.49 \pm 0.04$ & & $0.86 \pm 0.07$ & & $1.71 \pm 0.09$ & & $10.17 \pm 0.6$ & \\
\hline \multicolumn{11}{|c|}{$\begin{array}{c}\text { Days } \\
\text { post-anthesis }\end{array}$} \\
\hline 10 & $19.04 \pm 1.53$ & $\mathrm{a}$ & $1.34 \pm 0.09$ & $\mathrm{~b}$ & $1.77 \pm 0.17$ & $\mathrm{a}$ & $1.15 \pm 0.09$ & $\mathrm{~b}$ & $6.51 \pm 1.62$ & c \\
\hline 30 & $12.70 \pm 0.35$ & c & $1.55 \pm 0.02$ & a & $0.73 \pm 0.04$ & $\mathrm{bc}$ & $1.66 \pm 0.07$ & $\mathrm{a}$ & $12.15 \pm 0.2$ & $\mathrm{a}$ \\
\hline 40 & $14.35 \pm 0.39$ & $\mathrm{bc}$ & $1.56 \pm 0.04$ & a & $0.59 \pm 0.03$ & $\mathrm{c}$ & $1.94 \pm 0.07$ & $\mathrm{a}$ & $12.54 \pm 0.14$ & $\mathrm{a}$ \\
\hline 50 & $\underset{* * *}{13.71 \pm 0.37}$ & bc & $1.62 \pm 0.04$ & $\mathrm{a}$ & $\underset{* * *}{0.63 \pm 0.05}$ & c & $1.83 \pm 0.07$ & $\mathrm{a}$ & $\underset{* * *}{12.16} \pm 0.22$ & a \\
\hline
\end{tabular}

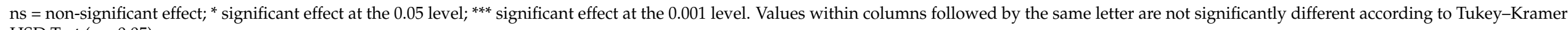
HSD Test $(p<0.05)$. 


\section{Conclusions}

Biostimulant application did not affect the yield attributes of grafted watermelon, most probably because the vigorous interspecific rootstock used had masked the latent biostimulant effect. The biostimulant effect could have potentially been significant had a less vigorous rootstock or different type of biostimulant been used [52]. Decline in pulp firmness was pronounced with the onset of cell enlargement and the decrease in cell density (10-30 dpa), concomitant with rapid fruit growth. The biostimulant effect on firmness was non-significant as this effect appears crop- and formulation-dependent; moreover, the phyto-hormonal potential of the biostimulant was likely confounded by the pronounced rootstock effect on pulp firmness. Likewise, rind thickness was not affected by the biostimulant and seemed largely determined by grafting, aside from the genotype. Pulp CIELAB colorimetric variables were determined solely by the ripening stage, with the most intense color attained at full ripeness ( $40 \mathrm{dpa}$ ). The application of protein hydrolysate biostimulant reduced flesh lycopene content by about $8 \%$ compared to the control. Fructose and glucose were the main substrates fueling the period of rapid fruit growth from 10 to $30 \mathrm{dpa}$, while sucrose was the main form of depository carbohydrate accumulating at the expense of mono-saccharides during the end of fruit ripening from 40 to $50 \mathrm{dpa}$. The total sugar content of the juice coevolved with SSC, both of which peaked at $30 \mathrm{dpa}$ and remained unchanged thereafter. Fruit acidity was determined solely by ripening and increased up to $20 \mathrm{dpa}$ and then followed a gradual decrease to stabilize after $40 \mathrm{dpa}$. Potassium was the most abundant mineral in the fruit pulp and reached its minimum level at the end of rapid fruit growth, around $30 \mathrm{dpa}$. Protein hydrolysate biostimulant effect on watermelon fruit ripening process is not granted, at least regarding the conditions this study was carried out under.

Supplementary Materials: The following are available online at https:/ / www.mdpi.com/article/10 .3390 /horticulturae7090313/s1, Table S1: Timetable of the experiment, Table S2: Mean comparisons for pulp firmness, fruit rind, flesh CIELAB color components and lycopene content of watermelon cv. Obla harvested at 10, 20, 30, 40 and 50 days post-anthesis with (PH) or without (Control) protein hydrolysate biostimulant application, Table S3: Mean comparisons for fruit content in soluble solids (SSC), glucose, fructose, sucrose, total soluble carbohydrates, sweetness index and titratable acidity (TA) obtained from water-melon cv. Obla harvested at 10, 20, 30, 40 and 50 days post-anthesis with $(\mathrm{PH})$ or without (Control) protein hydrolysate biostimulant application, Table S4: Mean comparisons for fruit content in $\mathrm{K}, \mathrm{Mg}$, Ca, P and dry matter (DM) obtained from watermelon cv. Obla harvested at 10, 20, 30, 40 and 50 days post-anthesis with (PH) or without (Control) protein hydrolysate biostimulant application.

Author Contributions: Conceptualization, G.A.S., M.C.K. and Y.R.; methodology, G.A.S., M.C.K. and Y.R.; validation, C.A., M.G.E. and A.C.K.; formal analysis, G.A.S., M.G.E. and A.C.K.; investigation, G.A.S., M.C.K. and M.G.E.; resources, M.C.K. and Y.R.; data curation, G.A.S.; writing-review and editing G.A.S., M.C.K. and Y.R.; supervision, M.C.K. and Y.R. All authors have read and agreed to the published version of the manuscript.

Funding: This research received no external funding.

Institutional Review Board Statement: Not applicable.

Informed Consent Statement: Not applicable.

Data Availability Statement: The datasets generated for this study are available on request to the corresponding author.

Conflicts of Interest: The authors declare no conflict of interest.

\section{References}

1. Kyriacou, M.C.; Rouphael, Y.; Colla, G.; Zrenner, R.; Schwarz, D. Vegetable Grafting: The Implications of a Growing Agronomic Imperative for Vegetable Fruit Quality and Nutritive Value. Front. Plant Sci. 2017, 8, 741. [CrossRef]

2. Rouphael, Y.; Kyriacou, M.C.; Colla, G. Vegetable Grafting: A Toolbox for Securing Yield Stability under Multiple Stress Conditions. Front. Plant Sci. 2018, 8, 2255. [CrossRef] 
3. Schwarz, D.; Rouphael, Y.; Colla, G.; Venema, J.H. Grafting as a Tool to Improve Tolerance of Vegetables to Abiotic Stresses: Thermal Stress, Water Stress and Organic Pollutants. Sci. Hortic. 2010, 127, 162-171. [CrossRef]

4. Colla, G.; Hoagland, L.; Ruzzi, M.; Cardarelli, M.; Bonini, P.; Canaguier, R.; Rouphael, Y. Biostimulant Action of Protein Hydrolysates: Unraveling Their Effects on Plant Physiology and Microbiome. Front. Plant Sci. 2017, 8, 2202. [CrossRef]

5. Colla, G.; Nardi, S.; Cardarelli, M.; Ertani, A.; Lucini, L.; Canaguier, R.; Rouphael, Y. Protein Hydrolysates as Biostimulants in Horticulture. Sci. Hortic. 2015, 196, 28-38. [CrossRef]

6. Du Jardin, P. Plant Biostimulants: Definition, Concept, Main Categories and Regulation. Sci. Hortic. 2015, 196, 3-14. [CrossRef]

7. Yakhin, O.I.; Lubyanov, A.A.; Yakhin, I.A.; Brown, P.H. Biostimulants in Plant Science: A Global Perspective. Front. Plant Sci. 2017, 7, 2049. [CrossRef] [PubMed]

8. Rouphael, Y.; Colla, G. Biostimulants in Agriculture. Front. Plant Sci. 2020, 11, 40. [CrossRef] [PubMed]

9. Kyriacou, M.C.; Soteriou, G.A.; Rouphael, Y.; Siomos, A.S.; Gerasopoulos, D. Configuration of Watermelon Fruit Quality in Response to Rootstock-mediated Harvest Maturity and Postharvest Storage. J. Sci. Food Agric. 2016, 96, 2400-2409. [CrossRef]

10. Fallik, E.; Ziv, C. How Rootstock/Scion Combinations Affect Watermelon Fruit Quality after Harvest? J. Sci. Food Agric. 2020, 100, 3275-3282. [CrossRef]

11. Kyriacou, M.C.; Soteriou, G. Quality and Postharvest Performance of Watermelon Fruit in Response to Grafting on Interspecific Cucurbit Rootstocks. J. Food Qual. 2015, 38, 21-29. [CrossRef]

12. Fathy, M.A.; Gabr, M.A.; El Shall, S.A. Effect of Humic Acid Treatments on 'Canino' apricot Growth, Yield and Fruit Quality. N. Y. Sci. J. 2010, 3, 109-115.

13. Soppelsa, S.; Kelderer, M.; Casera, C.; Bassi, M.; Robatscher, P.; Matteazzi, A.; Andreotti, C. Foliar Applications of Biostimulants Promote Growth, Yield and Fruit Quality of Strawberry Plants Grown under Nutrient Limitation. Agronomy 2019, 9, 483. [CrossRef]

14. Barrajón-Catalán, E.; Álvarez-Martínez, F.J.; Borras, F.; Perez, D.; Herrero, N.; Ruiz, J.J.; Micol, V. Metabolomic Analysis of the Effects of a Commercial Complex Biostimulant on Pepper Crops. Food Chem. 2020, 310, 125818. [CrossRef] [PubMed]

15. Gonçalves, B.; Morais, M.C.; Sequeira, A.; Ribeiro, C.; Guedes, F.; Silva, A.P.; Aires, A. Quality Preservation of Sweet Cherry cv. 'staccato' by Using Glycine-Betaine or Ascophyllum nodosum. Food Chem. 2020, 322, 126713. [CrossRef]

16. Colla, G.; Cardarelli, M.; Bonini, P.; Rouphael, Y. Foliar Applications of Protein Hydrolysate, Plant and Seaweed Extracts Increase Yield but Differentially Modulate Fruit Quality of Greenhouse Tomato. HortScience 2017, 52, 1214-1220. [CrossRef]

17. Rouphael, Y.; Colla, G.; Giordano, M.; El-Nakhel, C.; Kyriacou, M.C.; De Pascale, S. Foliar Applications of a Legume-Derived Protein Hydrolysate Elicit Dose-Dependent Increases of Growth, Leaf Mineral Composition, Yield and Fruit Quality in Two Greenhouse Tomato Cultivars. Sci. Hortic. 2017, 226, 353-360.

18. Ertani, A.; Pizzeghello, D.; Francioso, O.; Sambo, P.; Sanchez-Cortes, S.; Nardi, S. Capsicum chinensis L. Growth and Nutraceutical Properties Are Enhanced by Biostimulants in a Long-Term Period: Chemical and Metabolomic Approaches. Front. Plant Sci. 2014, 5, 375. [CrossRef]

19. Devi, P.; Perkins-Veazie, P.; Miles, C. Impact of Grafting on Watermelon Fruit Maturity and Quality. Horticulturae 2020, 6, 97. [CrossRef]

20. Frioni, T.; Sabbatini, P.; Tombesi, S.; Norrie, J.; Poni, S.; Gatti, M.; Palliotti, A. Effects of a Biostimulant Derived from the Brown Seaweed Ascophyllum nodosum on Ripening Dynamics and Fruit Quality of Grapevines. Sci. Hortic. 2018, 232, 97-106.

21. Tarantino, A.; Lops, F.; Disciglio, G.; Lopriore, G. Effects of Plant Biostimulants on Fruit Set, Growth, Yield and Fruit Quality Attributes of 'Orange Rubis ${ }^{\prime}$ 'Apricot (Prunus armeniaca L.) Cultivar in Two Consecutive Years. Sci. Hortic. 2018, 239 , 26-34. [CrossRef]

22. Soteriou, G.A.; Kyriacou, M.C. Rootstock-Mediated Effects on Watermelon Field Performance and Fruit Quality Characteristics. Int. J. Veg. Sci. 2015, 21, 344-362. [CrossRef]

23. Paul, K.; Sorrentino, M.; Lucini, L.; Rouphael, Y.; Cardarelli, M.; Bonini, P.; Miras Moreno, M.B.; Reynaud, H.; Canaguier, R.; Trtílek, M. A Combined Phenotypic and Metabolomic Approach for Elucidating the Biostimulant Action of a Plant-Derived Protein Hydrolysate on Tomato Grown under Limited Water Availability. Front. Plant Sci. 2019, 10, 493. [CrossRef] [PubMed]

24. McGuire, R.G. Reporting of Objective Color Measurements. HortScience 1992, 27, 1254-1255. [CrossRef]

25. Fish, W.W.; Davis, A.R. The Effects of Frozen Storage Conditions on Lycopene Stability in Watermelon Tissue. J. Agric. Food Chem. 2003, 51, 3582-3585. [CrossRef] [PubMed]

26. Kyriacou, M.C.; Soteriou, G.A.; Rouphael, Y. Modulatory Effects of Interspecific and Gourd Rootstocks on Crop Performance, Physicochemical Quality, Bioactive Components and Postharvest Performance of Diploid and Triploid Watermelon Scions. Agronomy 2020, 10, 1396. [CrossRef]

27. Maynard, D.N. Watermelons: Characteristics, Production, and Marketing; ASHS Press: Ashcroft, BC, Canada, 2001; ISBN 0-9707546-1-2.

28. Walters, S.A. Influence of Plant Density and Cultivar on Mini Triploid Watermelon Yield and Fruit Quality. HortTechnology 2009, 19, 553-557. [CrossRef]

29. Sinnott, E.W. A Developmental Analysis of the Relation between Cell Size and Fruit Size in Cucurbits. Am. J. Bot. 1939, 26, 179-189. [CrossRef]

30. Fukuoka, N.; Masuda, D.; Kanamori, Y. Effect of Timing of High Temperature Treatment around the Fruit on Sugar Accumulation in Watermelon (Citrullus Lanatus (Thunb.) Matsum. et Nakai). Environ. Control Biol. 2008, 46, 241-248. [CrossRef] 
31. Kyriacou, M.C.; Leskovar, D.I.; Colla, G.; Rouphael, Y. Watermelon and Melon Fruit Quality: The Genotypic and AgroEnvironmental Factors Implicated. Sci. Hortic. 2018, 234, 393-408. [CrossRef]

32. Soteriou, G.A.; Kyriacou, M.C.; Siomos, A.S.; Gerasopoulos, D. Evolution of Watermelon Fruit Physicochemical and Phytochemical Composition during Ripening as Affected by Grafting. Food Chem. 2014, 165, 282-289. [CrossRef]

33. Fernando, D.; Milagrosa, S.; Francisco, C.; Francisco, M. Biostimulant Activity of Trichoderma saturnisporum in Melon (Cucumis melo). Hortscience 2018, 53, 810-815. [CrossRef]

34. Soppelsa, S.; Kelderer, M.; Casera, C.; Bassi, M.; Robatscher, P.; Andreotti, C. Use of Biostimulants for Organic Apple Production: Effects on Tree Growth, Yield, and Fruit Quality at Harvest and during Storage. Front. Plant Sci. 2018, 9, 1342. [CrossRef]

35. Trandel, M.A.; Johanningsmeier, S.; Schultheis, J.; Gunter, C.; Perkins-Veazie, P. Cell Wall Polysaccharide Composition of Grafted 'Liberty' Watermelon with Reduced Incidence of Hollow Heart Defect. Front. Plant Sci. 2021, 12, 278. [CrossRef]

36. San Bautista, A.; Calatayud, A.; Nebauer, S.G.; Pascual, B.; Maroto, J.V.; López-Galarza, S. Effects of Simple and Double Grafting Melon Plants on Mineral Absorption, Photosynthesis, Biomass and Yield. Sci. Hortic. 2011, 130, 575-580. [CrossRef]

37. Liu, N.; Yang, J.; Guo, S.; Xu, Y.; Zhang, M. Genome-Wide Identification and Comparative Analysis of Conserved and Novel MicroRNAs in Grafted Watermelon by High-Throughput Sequencing. PLoS ONE 2016, 8, e57359. [CrossRef] [PubMed]

38. Soteriou, G.A.; Siomos, A.S.; Gerasopoulos, D.; Rouphael, Y.; Georgiadou, S.; Kyriacou, M.C. Biochemical and Histological Contributions to Textural Changes in Watermelon Fruit Modulated by Grafting. Food Chem. 2017, 237, 133-140. [CrossRef]

39. Anees, M.; Gao, L.; Umer, M.J.; Yuan, P.; Zhu, H.; Lu, X.; He, N.; Gong, C.; Kaseb, M.O.; Zhao, S. Identification of Key Gene Networks Associated with Cell Wall Components Leading to Flesh Firmness in Watermelon. Front. Plant Sci. 2021, $12,1164$. [CrossRef] [PubMed]

40. Proietti, S.; Rouphael, Y.; Colla, G.; Cardarelli, M.; De Agazio, M.; Zacchini, M.; Rea, E.; Moscatello, S.; Battistelli, A. Fruit Quality of Mini-watermelon as Affected by Grafting and Irrigation Regimes. J. Sci. Food Agric. 2008, 88, 1107-1114. [CrossRef]

41. Perkins-Veazie, P.; Collins, J.K.; Davis, A.R.; Roberts, W. Carotenoid Content of 50 Watermelon Cultivars. J. Agric. Food Chem. 2006, 54, 2593-2597. [CrossRef] [PubMed]

42. Perkins-Veazie, P.; Collins, J.K.; Pair, S.D.; Roberts, W. Lycopene Content Differs among Red-fleshed Watermelon Cultivars. J. Sci. Food Agric. 2001, 81, 983-987. [CrossRef]

43. Ilahy, R.; Tlili, I.; Siddiqui, M.W.; Hdider, C.; Lenucci, M.S. Inside and beyond Color: Comparative Overview of Functional Quality of Tomato and Watermelon Fruits. Front. Plant Sci. 2019, 10, 769. [CrossRef]

44. Magwaza, L.S.; Opara, U.L. Analytical Methods for Determination of Sugars and Sweetness of Horticultural Products-A Review. Sci. Hortic. 2015, 184, 179-192. [CrossRef]

45. Roussos, P.A.; Denaxa, N.; Damvakaris, T. Strawberry Fruit Quality Attributes after Application of Plant Growth Stimulating Compounds. Sci. Hortic. 2009, 119, 138-146. [CrossRef]

46. Brown, A.C., Jr.; Summers, W.L. Carbohydrate Accumulation and Color Development in Watermelon. J. Am. Soc. Hortic. Sci. 1985, 110, 683-687.

47. Rouphael, Y.; Cardarelli, M.; Colla, G.; Rea, E. Yield, Mineral Composition, Water Relations, and Water Use Efficiency of Grafted Mini-Watermelon Plants under Deficit Irrigation. HortScience 2008, 43, 730-736. [CrossRef]

48. Ertani, A.; Schiavon, M.; Nardi, S. Transcriptome-Wide Identification of Differentially Expressed Genes in Solanum lycopersicon L. in Response to an Alfalfa-Protein Hydrolysate Using Microarrays. Front. Plant Sci. 2017, 8, 1159. [CrossRef]

49. Huang, Y.; Li, J.; Hua, B.; Liu, Z.; Fan, M.; Bie, Z. Grafting onto Different Rootstocks as a Means to Improve Watermelon Tolerance to Low Potassium Stress. Sci. Hortic. 2013, 149, 80-85. [CrossRef]

50. Zhong, Y.; Chen, C.; Nawaz, M.A.; Jiao, Y.; Zheng, Z.; Shi, X.; Xie, W.; Yu, Y.; Guo, J.; Zhu, S. Using Rootstock to Increase Watermelon Fruit Yield and Quality at Low Potassium Supply: A Comprehensive Analysis from Agronomic, Physiological and Transcriptional Perspective. Sci. Hortic. 2018, 241, 144-151. [CrossRef]

51. Gruda, N.; Savvas, D.; Colla, G.; Rouphael, Y. Impacts of Genetic Material and Current Technologies on Product Quality of Selected Greenhouse Vegetables-A Review. Eur. J. Hortic. Sci. 2018, 83, 319-328. [CrossRef]

52. Bulgari, R.; Franzoni, G.; Ferrante, A. Biostimulants Application in Horticultural Crops under Abiotic Stress Conditions. Agronomy 2019, 9, 306. [CrossRef] 